Article

\title{
Climate Politics in Green Deals: Exposing the Political Frontiers of the European Green Deal
}

\author{
Juan Antonio Samper *, Amanda Schockling and Mine Islar \\ Lund University Centre for Sustainability Studies, Lund University, 22362 Lund, Sweden; \\ E-Mails: samper.j@javeriana.edu.co (J.A.S.), aschockl@alumni.nd.edu (A.S.), mine.islar@lucsus.lu.se (M.I.) \\ * Corresponding author
}

Submitted: 15 November 2020 | Accepted: 18 March 2021 | Published: 28 April 2021

\begin{abstract}
This article investigates the political attempts to frame European climate politics and provides a critical discourse analysis of the European Green Deal. A rapid transition towards low-carbon development across the world has been contested by discourses aiming to acknowledge the inseparability of social and ecological issues. These discussions are fairly new in the European context and in 2019, the European Commission presented its Communication on the European Green Deal-the European Union's legislative roadmap to carbon neutrality by 2050. Empirical evidence for this article is derived from process tracing and policy analysis of the European Commission's documents on the European Green Deal in relation to existing Green New Deals. Drawing from a neo-Gramscian perspective we argue that the European Green Deal is an attempt to extend the neoliberal hegemonic formation within European climate politics. This results in the foreclosure of democratic channels for articulating climate politics according to dissenting discourses, thereby avoiding the political contestation inherent to climate politics.
\end{abstract}

\section{Keywords}

climate politics; depoliticization; European Green Deal; hegemony; neoliberalism; sustainability

\section{Issue}

This article is part of the issue "Is There a New Climate Politics? Emergency, Engagement and Justice" edited by Anna R. Davies (Trinity College Dublin, Ireland), Stephan Hügel (Trinity College Dublin, Ireland) and Vanesa Castán Broto (University of Sheffield, UK).

(C) 2021 by the authors; licensee Cogitatio (Lisbon, Portugal). This article is licensed under a Creative Commons Attribution 4.0 International License (CC BY).

\section{Introduction}

On the 11th of December 2019, the European Commission communicated to the European Parliament and the Council, a document called the European Green Deal (EGD). The EGD played a key role in the approval of the Von der Leyen Commission and its political agenda (Gaventa, 2019). It occupied center stage as the most lobbied topic in Brussels during the first 100 days of Von der Leyen's term (Kergueno, 2020). The EGD is presented as a "growth strategy that aims to transform the EU into a fair and prosperous society, with a modern, resource-efficient and competitive economy" with zero emissions by 2050 (European Commission,
$2019 b$, p. 2). The EGD further imagines decoupling economic growth from resource inputs, a goal that is contested by several academics (European Commission, 2019b; Jackson, 2017; Kallis, Demaria, \& D'Alisa, 2015). The EGD also cites the Commission's commitment to a just, inclusive, and people-centered transition (European Commission, 2019b).

Several studies show that transitions are deeply political and involve considering the power relations and vested interests within energy systems (Haas, 2019; Kraushaar-Friesen \& Busch, 2020), examining the impact of deploying renewables and gas infrastructure to grow industrial output and consumption (Guðmundsdóttir, Carton, Busch, \& Ramasar, 2018), scrutinizing ownership 
of the means to produce renewable energy with its inherent hegemonic struggles (Haas, 2019; Islar, 2012), and understanding the disproportionate responsibility of the polity in driving climate change (Kartha, Kemp-Benedict, Ghosh, Nazareth, \& Gore, 2020; Lindt et al., 2017). Moreover, social resistance to sustainability agendas highlights the importance of recognizing the socioeconomic impacts of green transitions and the gap between the concerns of workers' struggles to meet the 'end of the month' versus the climate community's demand of avoiding the 'end of the world' (Martin \& Islar, 2020). Green New Deals (GNDs), in this context, offer an alternative to mitigating climate change through "egalitarian policies that prioritize public goals over corporate profits" and targeting investments in vulnerable, marginalized, and frontline communities (Aronoff, Battistoni, Cohen, \& Riofrancos, 2019, p. 14).

The European Trade Union Confederation (ETUC) published a set of key principles and guidelines that they recommend should be integrated into a future EGD to accurately capture the social impact of decarbonization. Trade unions also have asked the Commission to be formally included at all stages of the decisionmaking, policy implementation, and evaluation phases at European, national, sectoral, and regional levels (ETUC, 2020). Within this context, this article aims to contribute to a deeper understanding of the EGD in relation to existing GNDs by discussing if the European proposal provides possibilities and new opportunities to move beyond business as usual in the sphere of European climate politics. We argue that there is a need to explore the political frontiers that the Commission draws between reform and radical change to understand what is left out of the EGD, and the implications of such exclusions for the sustainable future of Europe. Empirical evidence for this article is derived from process tracing and policy analysis of the Commission's documents related to the EGD as well as a recent literature review on the GNDs in Europe and North America.

The article starts with neo-Gramscian perspectives on politicization. An explanation of the process tracing used for analyzing the EGD follows. Then, we continue with a brief contextualization of GNDs in Europe and North America in Section 4. In Section 5, we apply a process-tracing analysis and compare these developments with the EGD. In Section 6, we conclude by discussing the political frontiers of the EGD that define the core elements of European climate and energy (in)action.

\section{Neoliberal Hegemonic Formation and Sustainability}

Critical political theorists argue that current democratic politics have entered into a post-political chapter because the political, or the constitutive character of antagonism in human societies, is overlooked (Mouffe, 2005). By means of depoliticization, issues or people are excluded from democratic debates (Swyngedouw, 2013). Mouffe (2005) argues that depoliticization operates by drawing political frontiers while simultaneously denying their political character. Those excluded from these politically drawn boundaries are not considered as legitimate political adversaries. Rather, they are considered ignorant, uneducated, unmodern, and irrelevant. As a result, democratic institutions are weakened (Mouffe, 2005) and simultaneously the hegemonic framework is further tightened (Kraushaar-Friesen, 2019; Laclau \& Mouffe, 1985). In environmental politics, a post-political condition may be manifested in the sense that "the articulation of divergent, conflicting, and alternative trajectories of future environmental possibilities" is forestalled (Swyngedouw, 2013, p. 5).

Hegemony plays a central role in understanding post-political theory. Gramsci developed the concept of hegemony to describe the cultural, economic, political, and ideological domination of a socioeconomic class by means of both consent and coercion (Gramsci, 1999). Neo-Gramscian approaches affirm hegemony as a type of political relation that presupposes that the social cannot be totalized or fixed because of the plurality of "political and social spaces which do not refer to any ultimate unitarian basis" (Laclau \& Mouffe, 1985, p. 126). Therefore, hegemonic formations arise from articulating these political and social spaces according to a dominant discourse. In this context, the Gramscian concept of a war of position offers an analytical path to understand how hegemonic formations operate. Stegemann and Ossewaarde (2018) argue that the war of position refers to the strategic integration of counter-hegemonic positions into the hegemonic discourse. Floating signifiers, discursive elements with empty meaning and therefore contested in different political spaces, serve to make chains of equivalent meaning that allow a discursively logical incorporation (Laclau \& Mouffe, 1985). This discursive operation attempts to totalize meanings that were previously contested and therefore draws a frontier outside of which alternative meanings lie. When the incorporation is discursively achieved, the hegemonic formation is extended. This 'resulting myth' establishes a post-political condition while the political, antagonistic character of the counter-hegemonic position is neglected (Stegemann \& Ossewaarde, 2018).

Since the late 20th century, a neoliberal hegemonic formation has been steadily asserted over different political spaces. Neoliberalism can be considered as a 'process' instead of as an all-encompassing ideology with clear and demarcated end-states (Heynen \& Robbins, 2005). The term neoliberalization has been used by Peck and Tickell (2002) to emphasize the process-based, variegated character of contemporary processes of economic and political restructuring. To be more specific, their approach stresses the insight that neoliberal reforms are built on uneven institutional landscapes. These different landscapes can intensify reform processes or homogenize regulatory practices. It is therefore important to understand that contemporary neoliberal restructuring reforms take place, and are part of, ongoing transfor- 
mations of already existing regulations and systems in particular places and at particular times. This variegated approach emphasizes nationally or locally adapted neoliberal practices linked to the global system.

\section{Analytical Framework}

Process tracing can help with understanding how the discursive formation of neoliberalism is advanced in the EGD. Commonly used in qualitative social science research, process tracing is defined by its ambition to study causal mechanisms and causal relationships between independent variables and outcomes (Beach \& Pederson, 2013). We define the causal mechanism in question to be Mouffe's (2005) depoliticization and use process tracing to test this theorized causal mechanism. Mouffe postulates that the post-political is brought about by the drawing of political frontiers, followed by the subsequent exclusion of people or issues that sufficiently denies any political character or legitimacy of counter-hegemonic ideas. The methodological use of theory-testing process-tracing from Beach and Pederson (2013) is explained in Figure 1 with an example from the EGD's focus on transportation. At the empirical, casespecific level, we start by identifying a political frontier in the Commission's goal of reducing transportation emissions by $90 \%$. Through the process of exclusion, this goal excludes questions about the underlying factors that shape people's needs for travel in the first place. Such matters and their representatives are then excluded from any decision-making or goal setting. The Commission fails to ask why people must travel, either for working, living, etc., and deny the political nature of problems in relation to living and working locally. Through the process of neoliberalization, the Commission sets to achieve their goal of reducing transport emissions by developing and using alternative transport fuels, thus entering the post-political. The process tracing behind the analysis in Section 5 is explained by Figure 1 and is used to explicate the remaining environmental and social issues in the EGD.

\section{Green New Deals: Narratives for Climate Change Mitigation}

In the study of brief histories of GNDs, Mastini, Kallis, and Hickel (2021) reveal that little attention has been given to the fact that the content and framing of GNDs over the years has shifted. In what they refer to as 'GND 1.0,' an ecological modernization frame focused on investments in technological solutions is dominant. This frame is characterized as a technocratic exercise that seeks to revitalize capitalist investments by channeling financial means towards research and development, mild subsidies, and pricing carbon (Mastini et al., 2021). The 'GND 1.0' narrative in this sense can be tied to a neoliberal approach to climate politics insofar as it promotes market-friendly regulation, buttressing markets, and enabling resource mobilization and capital accumulation. Nevertheless, a different frame in GND proposals has emerged representing openness towards alternatives to the neoliberal approach.

The 'GND 2.0,' as coined by Mastini et al. (2021), originated in the aftermath of the G20 growth-friendly fiscal consolidation in 2010 where 16 of the $\mathrm{G} 20$ states failed to follow UNEP's 2009 recommendation of spending a mere $1 \%$ of GDP on green initiatives. The 'GND 2.0' "rejects the primacy of market-based environmental

\section{Theoretical level}

Causal Mechanism: Depoliticization

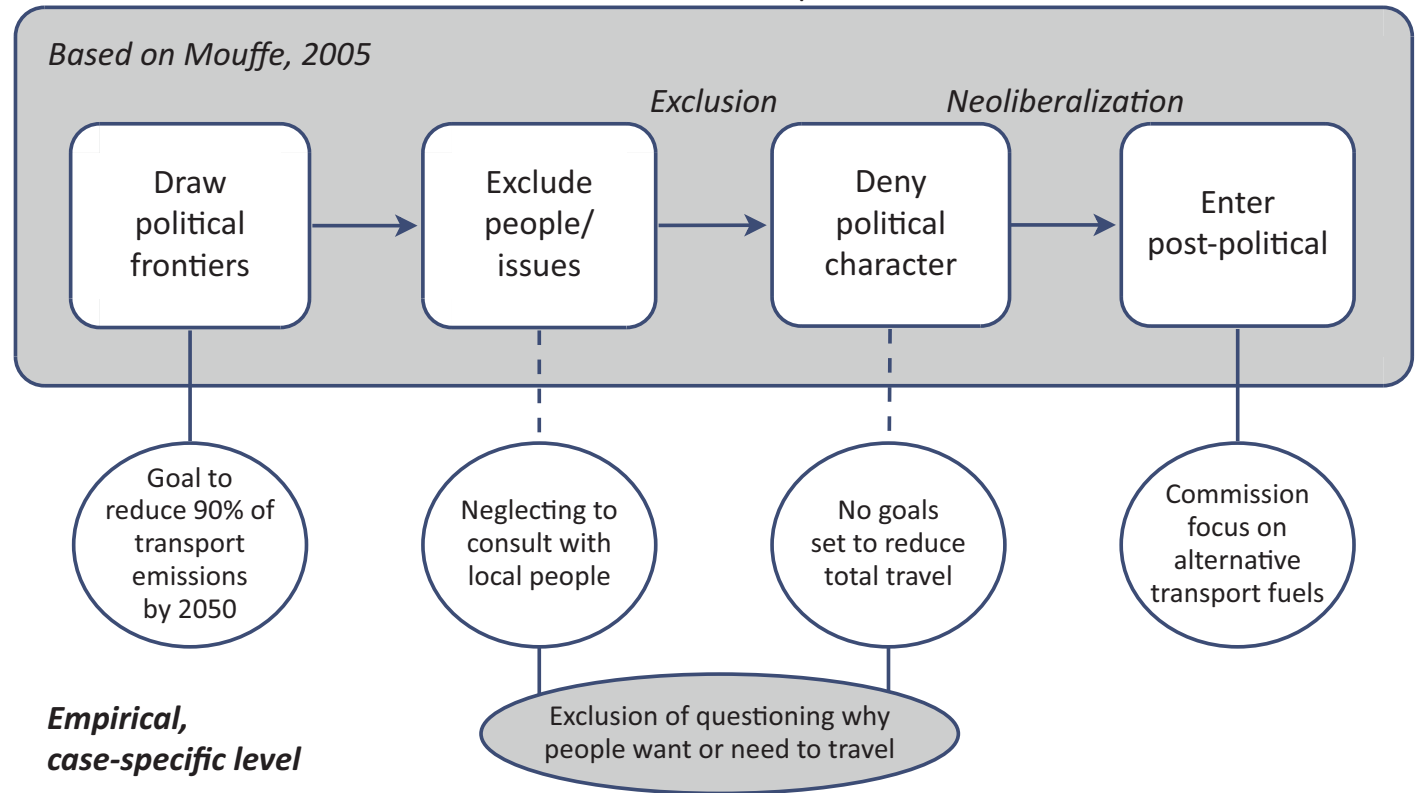

Figure 1. Author-created theory-testing process-tracing of depoliticization based on Beach and Pederson (2013). 
policy instruments" that construct our present ecological meltdown as a market failure to be fixed through pricing, rather than inseparable from, and a part of, a social crisis that can only be addressed by redistributing economic and political power ("A bold new plan," 2019; Mastini et al., 2021, p. 3). Thus, the 'GND 2.0' embraces command-and-control environmental regulation and prioritizes decarbonization at speed, scale, and scope by using the power of public investment and coordination (Aronoff et al., 2019), while also seeing itself as part of grass-roots movement building (Mastini et al., 2021).

'GND 2.0' is embedded in recent GND proposals. In the U.S., Congresswoman Alexandria Ocasio-Cortez led the introduction of House Resolution 109 (hereafter H. Res. 109) in the House of Representatives in early 2019 (Recognizing the duty of the Federal Government to create a Green New Deal, 2019). H. Res. 109 is a non-binding resolution or essentially a list of goals and not full-blown legislation. More concrete policies have yet to be drafted in order to require the government to make any changes or implement any steps towards mitigating the country's climate impacts or adapting to the impending climate changes. H. Res. 109 declares the duty of the U.S. government to create a GND to: (a) achieve net-zero greenhouse gas emissions through a fair and just transition for all communities and workers; (b) create millions of good, high-wage jobs and ensure prosperity and economic security for all; (c) invest in the infrastructure and industry to sustainably meet the challenges of the 21st century; (d) secure clean air and water, climate and community resiliency, healthy food, access to nature, and a sustainable environment for all; and (e) promote justice and equity by stopping current, preventing future, and repairing historic oppression of frontline and vulnerable communities-defined as indigenous peoples, communities of color, migrant communities, deindustrialized communities, depopulated rural communities, the poor, low-income workers, women, the elderly, the unhoused, people with disabilities, and youth. H. Res 109 is an important step towards expanding previously drawn political frontiers because it opens channels to counter-hegemonic discourses.

Another frame in recent GNDs is the 'GND without growth.' As opposed to the GND proposal H. Res. 109, the 'GND without growth' is not contained in one single document. It is attributed to the ideas of degrowth academics, mostly North American and European, and other movements such as the Democracy in Europe Movement 2025. The latter published the report called Blueprint for Europe's Just Transition containing a different GND for Europe (Democracy in Europe Movement $2025,2019)$. The report presents a set of proposals for socioeconomic, legislative, and institutional transformation while abandoning the dogma of GDP growth as the primary measure of progress. The recommended alternatives include increased public investment, democratization of the energy sector, a job guarantee, universal access to public services, resource caps, and environmen- tal justice measures for resource-providing communities (Adler, Wargan, \& Prakash, 2019; Mastini et al., 2021).

There are points of convergence and tensions between the GND H. Res. 109 and the 'GND without growth.' Kallis, Paulson, D'Alisa, and Demaria (2020, p. 68) argue that both proposals share the commitment to a rapid and massive deployment of renewables, the decarbonization of transport and agriculture, new or refurbished zero-carbon affordable housing, and reforestation and ecological restoration. Both also embrace social ownership of essential infrastructures and access to financial instruments like loans and subsidies for a more democratic control over the economy (Eskelinen, 2015; Marois, 2017). Furthermore, the idea of a just transition is mobilized in both narratives to point out the importance of co-creation of policies by involving labor unions and other stakeholders (Newell \& Mulvaney, 2013). Another point of convergence is the expansion of the welfare state, which involves de-commodifying essential services such as healthcare, housing and work; thus, placing them within the realm of social rights rather than privileges allocated by the market (Gough, 2017; Mastini et al., 2021). Last but not least, both share a commitment to environmental justice as both explicitly address the need to give voice to communities rich in energy resources and to fairly distribute the costs and benefits of energy extraction (Kallis et al., 2020).

The gap between these GND proposals presents several points of contention. Some of these tensions concern the use of technology in the expansion of renewables through the costs and risks they can entail (Kallis et al., 2020). Instead of technology dependence, a 'GND without growth' calls for a fundamental transformation in the way we think about energy to reduce our dependence and increase redundancy with renewables. Another tension lies in the realm of employment and the just transition. Whereas the ideas which inspired the GND H. Res. 109, like those proposed by Rhiana Gunn-Wright at the New Consensus think tank, aims for guaranteed work and a family-sustaining wage, a 'GND without growth' would rather focus on more progressive employment measures aimed at work time reduction and work sharing (Kallis et al., 2020), a worker-controlled production system (Barca, 2019), and embracing gratuity on top of the universality of basic services (Kallis et al., 2020; Mastini et al., 2021). Though the New Economics Foundation, originally part of the visionary group to propose a GND in 2008 for the U.K., now supports a four-day work week and higher wages. Furthermore, the 'GND without growth' implies that public finance arrangements do not require growing the economy as a whole (Kallis et al., 2020).

Finally, a more substantial but not necessarily irreconcilable tension between these GNDs is identified in terms of the political frontiers they draw along the lines of the structural change and their underlying values and ideology (Mastini et al., 2021). This tension addresses two different points. First, while the 'GND without growth' 
expands the realm of possibility by challenging capitalism and its incompatibility for degrowth, the 'GND 2.0' aims at reforming capitalism from the inside. Second, the 'GND 1.0"s emphasis on top-down, state-conducted action and the "GND 2.0"s call for bottom-up, prefigurative, grass-roots politics will not be easily resolved (Mastini et al., 2021, p. 7). This dilemma calls for further conversations about climate politics that recognize that neither waiting for neoliberal capitalism to end nor allowing for new cycles of green primitive accumulation and commodification of nature are acceptable (McCarthy, 2015; Pollin, 2018). In this sense, the tensions can be loosened by noting that GNDs may be worth fighting for. They may be the most promising political opportunity available for movements defending socio-ecological struggles, such as those under the degrowth umbrella, to include their struggles on the battlefield of climate politics (Heron, 2019; Riofrancos, 2019). We will use the above analysis comparing 'GND 1.0,' 'GND 2.0,' and 'GND without growth' as a reference point to analyze the EGD so that we can situate the EGD in the spectrum between reform and radical change.

\section{Analysis for the European Green Deal}

In the following sections, we share the results of our process-tracing and policy analysis on the European Commission's communication documents on the EGD. The Commission begins the EGD by defining it, first and foremost, as a growth strategy. In the introductory section, the Commission states that the aim of the EGD is to transform Europe into a fair and prosperous society: One that is competitive, where economic growth is decoupled from resource use, while tackling climate and environment-related challenges. The latter goal is even promoted to the category of being the present generation's "defining task" (European Commission, 2019b, p. 2). However, addressing climate and environmental challenges is not a new policy objective as much as the Commission defines it as this generation's defining task. For instance, decoupling economic activity from environmental harm has been part of the Commission's discourse at least throughout the entire 21st century (European Commission, 2001, 2014, 2018, 2019a, 2019b).

As in the case of the GNDs examined above, we find points of convergence and tension arising between them and the EGD. To begin with the convergence points, and in line with the 'GND 2.0' narrative, the Commission shows a clear intention to exercise more stringent top-down climate governance. It promotes strengthening its command-and-control powers over the climate ambition of Member States. Complementarily, it also embraces increasing the level of climate ambition of the EU's transition to net-zero emissions targets for both 2030 and 2050. In contrast, showing more resemblance to a 'GND 1.0' narrative, the Commission also makes a plea for technological advancement to play a central role by stating that "climate and resource fron- trunners" are needed "to develop the first commercial applications of breakthrough technologies in key industrial sectors by 2030," suggesting carbon-removal technology like BECCS are a top priority for the EGD agenda (European Commission, 2019b, p. 8).

The commitment to a rapid and massive deployment of renewables is another point where the EGD and the contemporary GNDs converge. The Commission affirms that decarbonizing the energy sector "is critical" (European Commission, 2019b, p. 6). It focuses specifically on the deployment of renewables while scantly addressing fossil fuels, implying that fossil gases will not necessarily be outlawed. The deployment of renewables explicitly promoted is the increase of offshore wind power and decarbonized gas. In this decarbonization strategy, market-based mechanisms occupy a central role, where trust for an energy transition is mostly placed on the competitiveness of renewables. Furthermore, energy efficiency, as opposed to a reduction in total energy use, is prioritized. Moreover, there is reason to doubt that energy-intensive industries will be adequately addressed and regulated within the EGD. So, whereas the EGD's aim of deploying renewables converges with the GNDs, the strategy may give rise to tensions between them given that the EGD's decarbonization strategy looks more like the 'GND 1.0' technocratic exercise of large-scale green investment and R\&D.

The decarbonization of transport and agriculture is yet another point where the EGD and the GND discourses converge. The Commission promises a $90 \%$ reduction in transport emissions by 2050 by boosting multimodal transport (European Commission, 2019b). Furthermore, the Commission insists that transport "become drastically less polluting, especially in cities," for which a "combination of measures should address emissions, urban congestion, and improved public transport" (European Commission, 2019b, p. 11). However, at the strategy level tensions rise once again. There is little to no direction provided on how to improve public transport as the decarbonization of transport for the Commission focuses on alternative transport fuels, such as sustainable aviation fuels. One potentially radical point is made when declaring that the price of transport should reflect the cost to the environment and human health, but the document has a limited scope for following through with a commitment or indication of implementing a tax accurately reflecting the true cost of carbon (European Commission, 2019b). The 2011 White Paper for Transport set the EU's goal for reduction of transport emissions to $60 \%$ of 1990 levels by 2050 (European Commission, 2011). While the EGD increases this goal, the level of detail about how this goal can be achieved is not clearer than before. Similarly, in the EGD's 'Farm to Fork' strategy, tensions arise at the strategy level as the Commission takes a reformist stance focusing on "feeding a fast-growing population" by taking advantage of the opportunities opened by "new technologies and scientific discoveries," while stimulating sustainable food consumption (European Commission, 
2019b, p. 11). The EGD ensures Member States' national strategic plans for agriculture reflect the ambition set out in the GND and 'Farm to Fork' strategy, indicating a desire to achieve goals and declarations of intentions but no real commitment or consequence for not meeting concrete, assessable indicators. Lastly, the EGD tasks the EU with developing "new innovative techniques" to protect crops from pests and diseases while ensuring sustainability of the system when decades-old approaches such as permaculture, no-till farming, or crop rotation are already-proven methods for sustainable land and crop management (European Commission, 2019b, p. 12).

There are additional convergence points between the EGD and the transformationist GND narratives. The EGD contains a strategy for housing as it promotes a 'renovation wave' of old buildings to make them more energy efficient, something also advocated for in the GND H. Res. 109. Reforestation and ecological restoration are featured in the EGD through different strategies to address biodiversity loss, forest degradation, and exploited fisheries, which are also mentioned in the GND H. Res. 109's aim to restore ecosystems and carbon sinks. The EGD attempts to empower citizens by, for example, embracing energy communities and strengthening environmental education, but the only real place for input and participation from citizens is through already existing citizen dialogues and assemblies. This demonstrates that the EGD recognizes social ownership of essential infrastructures in this transition, though the document lacks concrete strategies to allow for citizen input on the totality of initiatives proposed in the EGD and the chance for these initiatives to be viable or significant in the societal transition.

There are also outright tensions between the EGD and the GNDs. To begin with, the role of labor unions at the negotiation table is unclear, as it is never mentioned in the EGD. In the ETUC position paper on the EGD, there are proposals spanning many of the different initiatives that have followed the EGD such as the Climate Law, the Just Transition Fund, the Climate Pact, and the Circular Economy Plan. The ETUC points out that even though social partners are mentioned among the stakeholders, "We [ETUC] regret that no more attention is given to the role of trade unions and social dialogue to tackle climate change, especially at the company level" (ETUC, 2020, p. 5). Chief among ETUC's proposals is linking climate targets with robust social requirements, financing the transition through fair taxation and a bigger portion of the EU budget, a Just Transition Fund that ensures solidarity, a stronger focus on employment in the industrial strategy, and an update placing the EGD within the context of the Covid-19 pandemic (ETUC, 2020). In addition to ETUC's proposals, despite the GND H. Res. 109's explicit aims for high or decent wages for all, the EGD makes no such claim. Neither does it refer to working hours, working weeks, or worker-controlled production systems, as does the 'GND without growth' specifically. Importantly, the ETUC claims the percentages mentioned in the EGD "do not tell the whole story and that a target does not make a policy," indicating a call for a more viable document from the Commission detailing the means and mechanisms trade unions and others will have available to achieve the goals set out in the EGD (ETUC, 2020, p. 4).

A major friction between the EGD and the 'GND 2.0,' H. Res. 109, as well as the 'GND without growth' is in the realm of job security and essential services. Job security is not provided through use of a job guarantee, but rather through a financial strategy to re-skill or re-train workers from declining, carbon-intense industries and placement in 'new' economic sectors, which are not clearly defined (European Commission, 2019b). Though the GND H. Res. 109 is not a commitment from the U.S. government, but rather a goal, it does explicitly mention a job guarantee and the narrative could align with more radical strategies like work hour reduction or job sharing. Again, we see the EGD lacking in content and specificity with the absence of healthcare. Though it advocates for healthy food and a healthy environment, the only support of public health in the EGD is promised to come from the savings of building efficiency measures (European Commission, 2019b). Energy poverty is mentioned as an issue and building renovations given as the only solution, though no concrete strategy such as ensuring universality of access to energy is presented. Here the tension between the necessity to de-commodify essential services, as embraced by the transformationist GND narratives, and the opportunity to boost the economy in the EGD is at its clearest. While the GNDs utilize a momentous opportunity to progress the welfare state by de-commodifying and re-socializing public goods, the EGD strategy instead points them towards the market as a catchall solution.

Another evident tension is the differences in addressing environmental justice. The GND narratives are very clear by recognizing the risks of past, present, and future injustices suffered by frontline and vulnerable communities, as well as resource-rich countries, and the need to distribute the costs and benefits of the transition fairly. However, the EGD emphasizes the importance of 'green deal diplomacy' to promote and implement climate, environment, and energy policy across the world, keeping the door open for the EU to force other countries to follow suit, perhaps. However, this 'green deal diplomacy' pays little attention to the social and environmental injustices caused by the EU's resource and energy dependency on other parts of the world. In fact, the Commission reverts to a rather colonial attitude in the EGD by stating its intent to "work with global partners to ensure the EU's resource security and reliable access to strategic raw materials" (European Commission, 2019b, p. 22). Moreover, although the EGD contains a pollution strategy to protect citizens, there is little to no recognition of frontline and vulnerable communities or a fair distribution scheme of the costs and benefits of the pollution strategy, indicating a further side-lining and silencing of disadvantaged individuals and communities. 
The financial arrangements reveal yet another tension between the EGD and the GND narratives. The EGD is concerned with mainstreaming sustainability by "sending the right price signals" to achieve what the Commission calls sustainable and inclusive growth (European Commission, 2019b, p. 17). Furthermore, the Commission plans to "mobilize international investors" to allow the EU to "remain at the forefront of efforts to set up a financial system that supports global sustainable growth" (European Commission, 2019b, p. 22). The first tension in the financial plans lies in the EGD's plan of 'righting' the price signals, which clearly follows a market-based approach to climate politics, similar to that of the 'GND 1.0' narrative as characterized by Mastini et al. (2021). The second tension is more specific to the EGD as a growth strategy, for Europe and the world, in contrast with the 'GND without growth' narrative that proposes moving beyond financial requirements to grow the economy.

A final, broader tension between the EGD and the GND narratives consists in what Mastini et al. (2021) described as the degree of structural change involved. The EGD shows a Commission that is in some instances fully trapped by the older 'GND 1.0' form of climate politics. The clearest examples of this entrapment are at the level of financial arrangements and environmental justice, where both strategy and discourse resemble the old more than the new form of climate politics. In other instances, instead, we see a changed Commission in word, to the extent that it utilizes the discourses of the newer 'GND 2.0,' but not in action, demonstrated by the proposed modifying of old policy strategies in the case of energy, transport, agriculture, and job security. Yet in other instances, the EGD fully embraces the new 'GND 2.0' narrative, such as is the case for housing renovation and ecological restoration.

What does this mean for the degree of structural change possible for the EU? The EGD reflects a continuation of previous policies for different sectors but increases goals and measures of these policies to a crosssectoral level and introduces a common package for a green transition. In this sense, little structural change is expected from the EGD, which makes the methods of the 'GND 2.0' narratives unlikely to be used by the EU. In comparison to the 'GND 2.0' narratives, some of which attempt to embrace economic redistribution, the EGD does not allow such sites of struggle to open in climate politics. Rather, the EGD looks more like an attempt to re-define floating signifiers relevant to climate politics such as 'sustainability,' the meaning of which is even contested in the 'GND 2.0' narratives. In this way, chains of equivalence are permitted to exist between climate politics and the neoliberal hegemonic formation.

\section{Concluding Remarks: Political Frontiers of the European Green Deal}

The GND narratives accurately sketch how the deeply political aspect of climate politics is denied. On the one hand, the 'GND 1.0' narrative articulates climate politics according to the discourse of the neoliberal hegemonic formation. The object of climate politics according to this narrative is strictly addressing emissions and energy sources, while its political subject is humankind. On the other hand, the 'GND 2.0' narratives articulate the issues at stake in the sphere of climate politics according to a counter-hegemonic discourse where broader social concerns are inseparable from the ecological. The object of climate politics according to this narrative goes beyond the technical and involves addressing the socio-cultural and economic behaviors and institutional arrangements that drive or allow the rise of emissions in the first place. Such behaviors and arrangements, not distributed equally throughout humankind, constitute not only one political subject in the sphere of climate politics, but a plurality of subjects that are more or less responsible for the ecological crisis.

In the case of the EGD, the technocratic exercise that Mastini et al. (2021) refer to is reflected in the Commission's approach to climate politics strictly as a matter of emissions and energy sources. Except for those few instances in which the 'GND 2.0' narrative is fully adopted in the EGD, the Commission either remains trapped in the 'GND 1.0' narrative or tries to articulate climate politics using a 'GND 2.0' discourse without fully incorporating the necessary changes in terms of the object and the political subjects of climate politics.

Theoretically speaking, we can say that most of the time the Commission depoliticizes climate politics in the EGD by further articulating it strictly in terms of the neoliberal hegemonic formation, or by materializing a war of position in which the neoliberal hegemonic formation attempts to discursively incorporate counterhegemonic narratives. In either case, the antagonism or the political contestation inherent to climate politics is eliminated, foreclosing democratic channels to counterhegemonic articulations of climate politics. The result is that the EGD might only serve as a justification for EU Member States to delay implementing transformative climate policies and therefore perpetuate socioeconomic behaviors and institutional arrangements that are overly responsible for the climate crisis. The political frontiers of the EGD, and the tragedy of European current climate politics is, to paraphrase Gramsci, that the old climate politics are dying and the new cannot be born.

\section{Conflict of Interests}

The authors declare no conflict of interests.

\section{References}

A bold new plan to tackle climate change ignores economic orthodoxy. (2019, February 7). The Economist. Retrieved from https://www.economist.com/ finance-and-economics/2019/02/07/a-bold-new- 
plan-to-tackle-climate-change-ignores-economicorthodoxy

Adler, D., Wargan, P., \& Prakash, S. (2019). Blueprint for Europe's just transition. GND for Europe. Retrieved from https://report.gndforeurope.com

Aronoff, K., Battistoni, A., Cohen, D. A., \& Riofrancos, T. (2019). A planet to win: Why we need a green new deal. London and New York, NY: Verso.

Barca, S. (2019). The labor(s) of degrowth. Capitalism Nature Socialism, 30(2), 207-216.

Beach, D., \& Pederson, R. B. (2013). Process-tracing methods: Foundations and guidelines. Ann Arbor, MI: University of Michigan Press.

Democracy in Europe Movement 2025. (2019). A blueprint for Europe's just transition (2nd ed.). Democracy in Europe Movement 2025. Retrieved from https://report.gndforeurope.com

Eskelinen, T. (2015). Possibilities and limits of green Keynesianism. In K. Borgnäs, T. Eskelinen, J. Perkiö, \& R. Warlenius (Eds.), The politics of ecosocialism (pp. 101-115). London: Routledge.

European Commission. (2001). Environment 2010: Our future, our choice: 6th EU Environment action programme 2001-2010. Brussels: European Commission.

European Commission. (2011). Roadmap to a single European transport area-Towards a competitive and resource efficient transport system. (COM(2011) 144 final). Brussels: European Commission.

European Commission. (2014). Guidelines on state aid for environmental protection and energy 2014-2020 (2014/C 200/01). Brussels: European Commission.

European Commission. (2018). Communication from the Commission to the European Parliament, the European Council, the Council, the European Economic and Social Committee, the Committe of the Regions and the European Investment bank: A Clean planet for all: A European strategic long-term vision for a prosperous, modern, competitive and climate neutral economy (COM(2018) 773 final). Brussels: European Commission.

European Commission. (2019a). Clean energy for all Europeans. Luxembourg: European Union.

European Commission. (2019b). The European Green Deal: Communication from the Commission to the European Parliament, the European Council, the Council, the European Economic and Social Committee and the Committee of the Regions (COM(2019) 640 final). Brussels: European Commission.

European Trade Union Confederation. (2020). ETUC resolution on European Green Deal initiatives: Climate Law, EU Sustainable Investment Plan, Just Transition Fund Regulation and new EU industrial strategy. Brussels: European Trade Union Confederation. Retrieved from https://www.etuc.org/system/files/ document/file2020-06/Adopted\%20-\%20ETUC\% 20Resolution\%20on\%20EGD\%20initiatives\%20\%20EN_0.pdf
Gaventa, J. (2019). How the European Green Deal will succeed or fail. Washington, DC: E3G. Retrieved from https://www.e3g.org/wp-content/uploads/5_12_ 19_E3G_How_the_European_Green_Deal_will_ succeed_or_fail.pdf

Gough, I. (2017). Heat, greed and human need: Climate change, capitalism and sustainable wellbeing. Cheltenham: Edward Eldar Publishing, Inc.

Gramsci, A. (1999). Selections from the prison notebooks of Antonio Gramsci. London: The Electronic Book Company Ltd.

Guđmundsdóttir, H., Carton, W., Busch, H., \& Ramasar, V. (2018). Modernist dreams and green sagas: The neoliberal politics of Iceland's renewable energy economy. Environment and Planning E: Nature and Space, 1(4), 1-23. https://doi.org/10.1177/ 2514848618796829

Haas, T. (2019). Struggles in European Union energy politics: A Gramscian perspective on power in energy transitions. Energy Research \& Social Science, 48, 66-74. https://doi.org/10.1016/j.erss.2018.09.011

Heron, K. (2019). Capitalists fear the Green New Deal: And for good reason. Roar Magazine. Retrieved from https://roarmag.org/essays/capitalists-fearthe-green-new-deal-and-for-good-reason

Heynen, N., \& Robbins, P. (2005). The neoliberalization of nature: Governance, privatization, enclosure and valuation. Capitalism Nature Socialism, 16(1), 5-8.

Islar, M. (2012). Privatized hydropower development in Turkey: A case of water grabbing. Water Alternatives, 5(2), 376-39.

Jackson, T. (2017). Prosperity without growth. New York, NY and London: Routledge.

Kallis, G., Demaria, F., \& D'Alisa, G. (2015). Introduction: Degrowth. In G. D’Alisa, F. Demaria, \& G. Kallis (Eds.), Degrowth: A vocabulary for a new era (Vol. 1, pp. 36-65). New York, NY and London: Routledge.

Kallis, G., Paulson, S., D’Alisa, G., \& Demaria, F. (2020). The case for degrowth. Cambridge: Polity Press.

Kartha, S., Kemp-Benedict, E., Ghosh, E., Nazareth, A., \& Gore, T. (2020). The carbon inequality era. Stockholm Environment Institute. Retrieved from https://www. sei.org/publications/the-carbon-inequality-era

Kergueno, R. (2020). 100 days of Commission lobbying. Transparency International EU. Retrieved from https://transparency.eu/100-days-lobbying

Kraushaar-Friesen, N., \& Busch, H. (2020). Of pipe dreams and fossil fools: Advancing Canadian fossil fuel hegemony through the Trans Mountain pipeline. Energy Research \& Social Science, 69. https://doi. org/10.1016/j.erss.2020.101695

Kraushaar-Friesen, N. E. (2019). "No country would find 173 billion barrels of oil in the ground and just leave them there": Examining the hegemony of fossil fuels in the Trudeau government's discourse on the Trans Mountain Pipeline expansion project (Master's dissertation). Lund University, Lund, Sweden.

Laclau, E., \& Mouffe, C. (1985). Hegemony and socialist 
strategy: Towards a radical democratic politics (2nd ed.). London and New York, NY: Verso Books.

Lindt, M. v. d., Emmert, S., Tukker, A., Anger-Kraavi, A., Neuhoff, K., Blachowicz, A., . . . CrawfordBrown, D. (2017). Carbon-CAP D8.2 final project report. Brussels: Climate Strategies. Retrieved from https://climatestrategies.org/wp-content/uploads/ 2017/06/CCAP-Final-Report.pdf

Marois, T. (2017). How public banks can help finance a green and just energy transformation. The Transnational Institute. Retrieved from https://www.tni.org/ en/publication/how-public-banks-can-help-financea-green-and-just-energy-transformation

Martin, M., \& Islar, M. (2020). The 'end of the world' vs. the 'end of the month': Understanding social resistance to sustainability transition agendas, a lesson from the Yellow Vests in France. Sustainability Science, 16, 601-614. https://doi.org/10.1007/s11625020-00877-9

Mastini, R., Kallis, G., \& Hickel, J. (2021). A green new deal without growth? Ecological Economics, 179. https:// doi.org/10.1016/j.ecolecon.2020.106832

McCarthy, J. (2015). A socioecological fix to capitalist crisis and climate change? The possibilities and limits of renewable energy. Environment and Planning A: Economy and Space, 47(12), 2485-2502.

Mouffe, C. (2005). On the political. London and New York,
NY: Routledge.

Newell, P., \& Mulvaney, D. (2013). The political economy of the 'just transition.' The Geographical Journal, 179(2). https://doi.org/10.1111/geoj.12008

Peck, J., \& Tickell, A. (2002). Neoliberalizing space. Antipode, 34(3), 380-404.

Pollin, R. (2018). De-growth vs a Green New Deal. New Left Review, II(2). https://newleftreview.org/issues/ ii112/articles/robert-pollin-de-growth-vs-a-greennew-deal

Recognizing the duty of the Federal Government to create a Green New Deal, H.Res.109, 116th Congress. (2019). Retrieved from https://www.congress.gov/ bill/116th-congress/house-resolution/109/text

Riofrancos, T. (2019). Plan, mood, battlefield: Reflections on the green new deal. Viewpoint Magazine. Retrieved from https://viewpointmag.com/2019/ 05/16/plan-mood-battlefield-reflections-on-thegreen-new-deal

Stegemann, L., \& Ossewaarde, M. (2018). A sustainable myth: A neo-Gramscian perspective on the populist and post-truth tendencies of the European green growth discourse. Energy Research \& Social Science, 43, 25-32. https://doi.org/10.1016/j.erss. 2018.05.015

Swyngedouw, E. (2013). The non-political politics of climate change. $A C M E, 12(1), 1-8$.

\section{About the Authors}

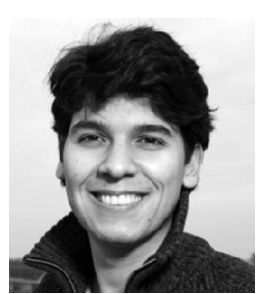

Juan Antonio Samper is a Colombian MSc Student in Environmental Studies and Sustainability Science at Lund University (Class of 2021). His main fields of interest are environmental politics and social movements. Juan is currently working on his master's thesis where he is researching socio-environmental conflict and the defense of the territory in the Andean-Amazonic region of Putumayo, Colombia.

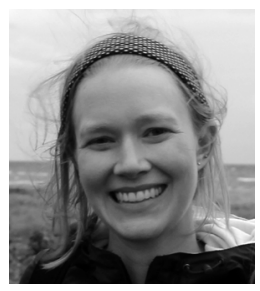

Amanda Schockling, from Sugar Land, Texas, U.S., is a MSc Student in the Environmental Studies and Sustainability Science program (LUMES) at Lund University. She is currently writing her thesis on the emerging socio-environmental movement in the U.S. involving the Sunrise Movement and the Democratic Socialists of America. She is interested in degrowth, social movements, and environmental economics and politics.

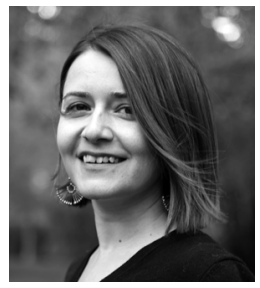

Mine Islar is an Associate Professor at Lund University Center for Sustainability Studies (LUCSUS). In her research she combines critical reading of the current sustainability solutions from a justice perspective together with studies of collective action as agency for change. Her empirical work includes collective action practices from Nepal, Denmark, Spain and Turkey. 